\title{
Do Strategic Agility Measures Affect Overall Firm Performance of Oil and Gas Industry? An Empirical Investigation
}

\author{
M. A. Arokodare, Ph.D \\ Correspondence: M. A. Arokodare, Ph.D, Babcock University, Illishan, Ogun State, Nigeria \\ Dr. M. A. Arokodare is currently the Chairman of First Ally Asset Management Company Limited and CEO of \\ M \& G Portfolio Limited. He was formerly Group Executive Director/CFO of Nigerian National Petroleum \\ Corporation
}

\begin{abstract}
The dynamic effect of strategic agility measures on performance of oil and gas companies have become a major challenge to and focus of scholars due to the vital role played by the oil and gas industry in the global economy. However, the industry in Nigeria have been faced with the problems of unstable overall performance indicators due to poor strategic agility approach towards price turmoil, dynamic market forces and instability of fiscal administration. Therefore, this study examined the effect of strategic agility measures on overall performance of oil and gas marketing companies in Lagos State, Nigeria. The study adopted cross-sectional survey research design with total enumeration of population of 515 retail station managers of major oil and gas marketing companies in Lagos State, Nigeria. The research instrument was found reliable and valid with Cronbach's alpha and KMO greater than 0.7 and 0.5 respectively and the primary data was analyzed using pre and post tests, pearson correlation, and multiple regression methods of analyses. Findings revealed that strategic agility measures except external response orientation (strategic foresight, strategic insight, internal response orientation, human resources capability, information technology capability) have positive and significant effect on overall firm performance of oil and gas marketing companies in Lagos State, Nigeria. The study concluded that strategic agility measures affected overall firm performance of the selected oil and gas marketing companies. Therefore, it was recommended that oil and gas marketing companies in Nigeria should embrace the propositions of the dynamic capabilities theory to enhance their strategic agility patterns and also adopt strategic agility measures to facilitate continuous development of their capabilities for sensing and seizing opportunities from the environment. This will enhance their proactiveness and promote agile workforce towards improving their targeted overall performance over their competitors. Implications of the results were discussed, limitations of the study highlighted, and future research directions outlined.
\end{abstract}

Keywords: Dynamic capabilities, Nigeria, Overall firm performance, Strategic agility, Oil and gas marketing companies

DOI: $10.7176 / \mathrm{EJBM} / 13-3-05$

Publication date: January $31^{\text {st }} 2021$

\section{Introduction}

The dynamic trend in and the unpredictable challenges of the global oil and gas industry have extremely triggered oil price volatility and market demand-supply forces all of which combined with increasingly stringent environmental regulations that stunt the performance of oil and gas companies across the globe. These aforementioned challenges in the oil and gas industry have captured the interest of professionals and scholars due to their adverse effects on oil and gas firm performance measures and significant contribution of the industry to economic activities across the globe. PricewaterhouseCoopers (2019) noted that the price turmoil, dynamic market forces and instability of fiscal administration in host nations amounted to significant pressure on the oil and gas industry performance in all economies of the world, whether developed, emerging and/or developing. This reduced the overall performance of this industry and created insecurity for the entire firm investment policy and financial strategy. The challenges of unstable performance indicators such as market share, firm profitability, competitive advantage and customer satisfaction among oil and gas companies were not only recorded in emerging and developing economies but also in developed economies (Mojarad, Atashbari, \& Tantau, 2018).

International Energy Agency (2020) asserted that world oil has experienced various kinds of shocks ranging from price turmoil, fiscal maladministration, unfavorable oil policies among others. However, none has hit the oil and gas companies and the entire economies of the world as much as the effects of the global crisis caused by the coronavirus (COVID-19) pandemic where demand shocks have collapsed oil prices with the consequence of a meltdown of the performance of the oil and gas companies worldwide (Engebretsen \& Anderson, 2020). Specifically, in emerging and developing economies like China, Malaysia, Singapore, South Korea, Ghana, South Africa, Nigeria among others, oil and gas companies have recorded unstable performance due to global shock, unpredicted economic policies, oil price volatility, dynamic market forces, technological advancement among others (Arokodare, 2020; International Energy Agency, 2020). Scholars such as Oyerinde, Olatunji, and Adewale (2018) and Arokodare and Asikhia (2020) argued that for oil and gas firms to manage and overcome unavoidable 
challenges inherent in the oil and gas industry, there is need for strategic agility (SA) measures such as strategic foresight, strategic insight, internal response orientation, external response orientation, human resources capability, and information technology capability. This indicates that oil and gas companies within and outside developed, emerging and developing economies cannot survive without adoption of SA as a way of doing business. This entails the engagement of SA initiatives which include the ability of the organizations to sense changes in dynamic and fast-paced environments, and to quickly respond to these changes by seizing market opportunities through reconfiguration of the organisations' capabilities (Arokodare, 2020).

In view of the established and significant role played by SA measures in securing overall firm performance amidst challenges such as oil shock, unpredicted economic policies, oil price volatility, market forces, technological advancement, scholars viewed SA as the firm's flexible ability to prepare for uncertain policies and business environmental risk factors in order to attain the desired firm performance (Al-Romeedy, 2019). TabeKhoshnood and Nematizadeh (2017) posited that without sound and timely adoption of SA measures, firms might record downturn in overall performance. The current level of globalized and knowledge-based economy in today's 21 st century have made oil and gas marketing companies to struggle to dynamically manage aforementioned challenges so as to achieve targeted overall performance. In this regard, Arokodare, Makinde, and Fakunmoju (2020) pointed out that most oil and gas marketing companies in Nigeria have recorded downturn in firm performance due to delayed adoption of SA measures as well as slow agility response to challenges of technological development, globalization, innovation, creativity, and changing customers' preferences. Furthermore, Arokodare and Asikhia (2020) and Oyerinde et al. (2018) emphasized that most oil and gas marketing companies in Nigeria were characterized by insensitivity, delay in strategic response to global oil shock, inconsistent oil policy and regulations in Nigeria and oil price variability. Thus, oil and gas marketing companies in Nigeria lack SA measures which in turn resulted in sharp decline in their overall firm performance. Although, several studies reviewed on the link between SA and firm performance within and outside Nigeria contexts focused on different industries such as airline, banking, telecommunication, manufacturing (Alhadid, 2016; Al-Romeedy, 2019; Amniattalab \& Ansari, 2016; Appelbaum, Calla, Desautels, \& Hasan, 2017; Arbussa, Bikfalvi, \& Marquès, 2017; Chirchir, 2015; Doz \& Kosonen, 2008; Mavengere, 2013; Nejatian, Zarei, Nejati, \& Zanjirchi, 2018; Ofoegbu \& Akanbi, 2012; Ojha, 2008; Oyedijo, 2012 among others), however, the study by Arokodare (2020) focused on the effect of SA on firm performance in the oil and gas industry, the marketing sector specifically. This indicated that there were scanty studies that focused on the link between SA measures (strategic foresight, strategic insight, internal response orientation, external response orientation, human resources capability, information technology capability) and performance in the oil and gas industry especially in Nigeria. Therefore, there existed a research gap which in turn served as the motivation for this study.

The rest of this article is structured as follows. Section 2 reviews existing literature on the study variables, and develops the theoretical framework and the hypotheses. Section 3 describes the methodology adopted for the study. Section 4 reports the main results and discusses the findings while Section 5 highlights some implications of the study. Section 6 presents the article's conclusions and outlines some recommendations for management. The last section highlights the limitations of the study and suggestions for future research.

\section{Literature Review, Theoretical Framework and Conceptual Model}

Strategic agility (SA) was defined by Tallon and Pinsonneault (2011) as the ability of a company to respond fast to the changes in the business environment, adapt to the changes and take actions that are aimed at controlling uncertainty. Nazir and Pinsonneault (2012) described SA as the ability of sensing and responding to internal and external changes; while Queiroz, Tallon, Sharma, and Coltman (2018) defined it as the ability to detect and react in an agile manner, to threats and opportunities emerging from the environment. The common themes in these definitions are the business environment, changes (opportunities and threats) from the environment, and the detection of and the reaction to these changes by the business organization. In line with these themes and the threedimensional conceptualization of SA by Mavengere (2013) which was echoed by Anggraini and Sudhartio (2019), SA was defined by Arokodare (2020) as "the ability of the organisation to sense changes in dynamic, fast-paced environments, and to quickly respond to these changes by seizing market opportunities and maintaining competitiveness through building, combining, enhancing, mobilising and reconfiguring its capabilities and in the process attaining and sustaining superior performance beyond its competition" (p. 45). This definition recognized the dimensions of strategic sensitivity, strategic response and collective capabilities with the ultimate objective of the organization being the attainment and sustainance of superior overall firm performance. The definition also recognized SA as a management tool for creating competitive advantage for the organization as it becomes expedient for the organization not only to recognize its industry dynamics (internal and external) but also to respond to it through fast strategy to ensure survival by way of superior performance. It is the organisation's penchant for adjusting its business model to the unpredictable changes of the business environment in order to achieve an increased level of value to the stakeholders.

Several studies relating SA to firm performance in different industries were reviewed except for the paucity 
of studies on the link between SA and firm performance in the oil and gas industry which form the empirical gap that needed to be filled. Literature such as Uğurlu, Çolakoğlu, and Öztosun (2018) and Clauss, Abebe, Tangpong, and Hock-Dopgen (2019) empirically examined how SA affects the performance of manufacturing companies and their studies revealed that SA positively and significantly affects manufacturing companies' performance. Their studies further asserted that SA is a vital scope that manufacturing companies need to adopt and employ in order to operate and survive in today 21 st century business environment which features business factors characterized by uncertainty and dynamism. Similarly, Lungu (2020) on the IT sector in Romania and Shin, Lee, Kim, and Rhim (2015) on the Korean small and medium enterprises, investigated the influence of SA on SMEs performance and firm operational performance. Their studies found that SA positively enhanced SMEs performance and operational performance. Also, they established that for a company to react fast to the changes of the business environmental risk factors and adapt to the risk factors of business uncertainty, SA measures must be employed.

Furthermore, Tallon and Pinsonneault (2011) empirically revealed that organisational agility reflects a firm's ability to sense environmental change and respond readily to customer demand. Orojloo, Feizi and Najafabadi (2016) showed that SA has a significant positive effect on organisational performance and that among factors affecting SA is strategic foresight which has the highest effect on the organisational performance and market share. Alon, Madanoglu and Shoham (2017) found that executives of franchising firms can create and sustain SA as economic conditions change by shifting resources between company-owned and franchising modalities, thus exhibiting SA through resource fluidity and expanding their market share through franchising-based growth. Relatedly, Lewis, Andriopoulos and Smith (2014) asserted that business agility provides capability for an organisation to contain changes in the marketplace and exploit market opportunities with speed and dexterity in order to gain competitive advantage. Hadad (2017) empirically upheld that having a SA and thinking represents a competitive advantage to secure the future position and performance of an organisation in the market. Muthoni (2015) investigated the influence of SA on competitive capability of private universities in Kenya while Okotoh (2015) conducted a study on the influence of SA on operational performance of Trademark East Africa. Both Muthoni (2015) and Okotoh (2015) found that SA has positive and significant effect on firm competitive capability and operational performance. However, various studies have shown that the reason for failure of some organisations is inattention to the changes in the dynamic environment and lack of suitable SA and plans for these conditions which result in not providing the right product at the right time for the right customer, and thus creating problem of decline in organisational performance (Amin-Beidokhti \& Zargar, 2012; Zaridis \& Mousiolis, 2014). Considering past empirical studies reviewed, it can be deduced that there existed empirical gap investigating the effect of SA measures on overall firm performance of oil and gas marketing companies within and outside Nigerian context. In the light of above empirical gap in literature reviewed, the hypothesis was developed for this study:

H01: Strategic agility measures have no significant effect on overall firm performance of oil and gas marketing companies in Lagos State, Nigeria

\section{Theoretical Framework}

This study was theoretically anchored on Dynamic Capabilities Theory (DCT) as baseline theory, since the DCT dynamically explains how firms could react and respond to the uncertain features of the business environment so as to survive economic risk hurdle and gain superior performance. This theory was selected to guide this study because its perspectives are tied to the focus of the study and the variables under investigation. The DCT is the capability of an organization to purposefully adapt an organization's resource base. Dynamic capabilities theory, which was developed by Teece, Pisano and Shuen (1997) was defined as "the firm's ability to integrate, build, and reconfigure internal and external competences to address rapidly changing environments" (p. 516) and it examines how firms address or bring about changes in their turbulent business environment through reconfiguration of their firm-specific competencies into new competencies (Teece, 2007). The DCT emerged as both an extension to and a reaction against the resource-based view (RBV) and its inability to interpret the development and redevelopment of resources and capabilities to address rapidly changing environment (Bleady, Ali, \& Ibrahim, 2018). The concept of DCT explained the mechanism that links resources and product markets to competitive advantage and firm survival. The DCT further explains how firms gain sustainable competitive advantage and survive in competitive and turbulent business environments in several ways.

The DCT framework works on three fundamental presumptions: the capacity to sense and shape opportunities, the ability to seize those opportunities, and the capability to maintain competitiveness through reconfiguring the enterprise's assets (Teece, 2007). Despite the popularity and insightful theoretical foundation, the DCT approach does not answer all questions of sustainable competitive advantage. Zahra, Sapienza and Davidsson (2006) argued that there were some inconsistencies and ambiguities in the literature of DCT. Another criticism of the concept is that DCT are difficult to measure empirically.

The DCT framework helps scholars to understand the foundations of long-run enterprise success while helping managers delineate relevant strategic considerations and the priorities they must adopt to enhance enterprise performance and escape the zero profit tendency associated with operating in markets open to global competition (Teece, 2007). The framework integrates the strategy and innovation literature and highlights the most 
important capabilities that the management need in order to sustain superior long run business performance (Teece, 2007). Easterby-Smith, Lyles and Peteraf (2009) emphasized that dynamic capabilities are higher-level capabilities, which enable knowledge gathering, fast response, sharing, and continual updating of the operational processes, interaction with the environment and decision-making evaluations in order to achieve firm competitive advantages and performance. Esbach (2009) also viewed dynamic capabilities as the capacity of an organization to purposefully create an agile firm and modify firm resource base so as to gain competitive advantage and other overall performance indicators. The justification for this theory employed in this study is based on the dynamic nature of oil and gas industry which was best explained by the DCT that strategic agility measures and theoretical explanation determine overall firm performance. The DCT perspective on the link between SA and firm overall performance concept delve into the researcher's conceptual model. The conceptual model depicted how SA measures (strategic foresight, strategic insight, internal response orientation, external response orientation, human resources capability, information technology capability) affect overall firm performance indicators (market share, firm profitability, firm efficiency, competitive advantage, customer satisfaction and firm creativity).

The researcher's conceptual model could be depicted as shown below in figure 2.1

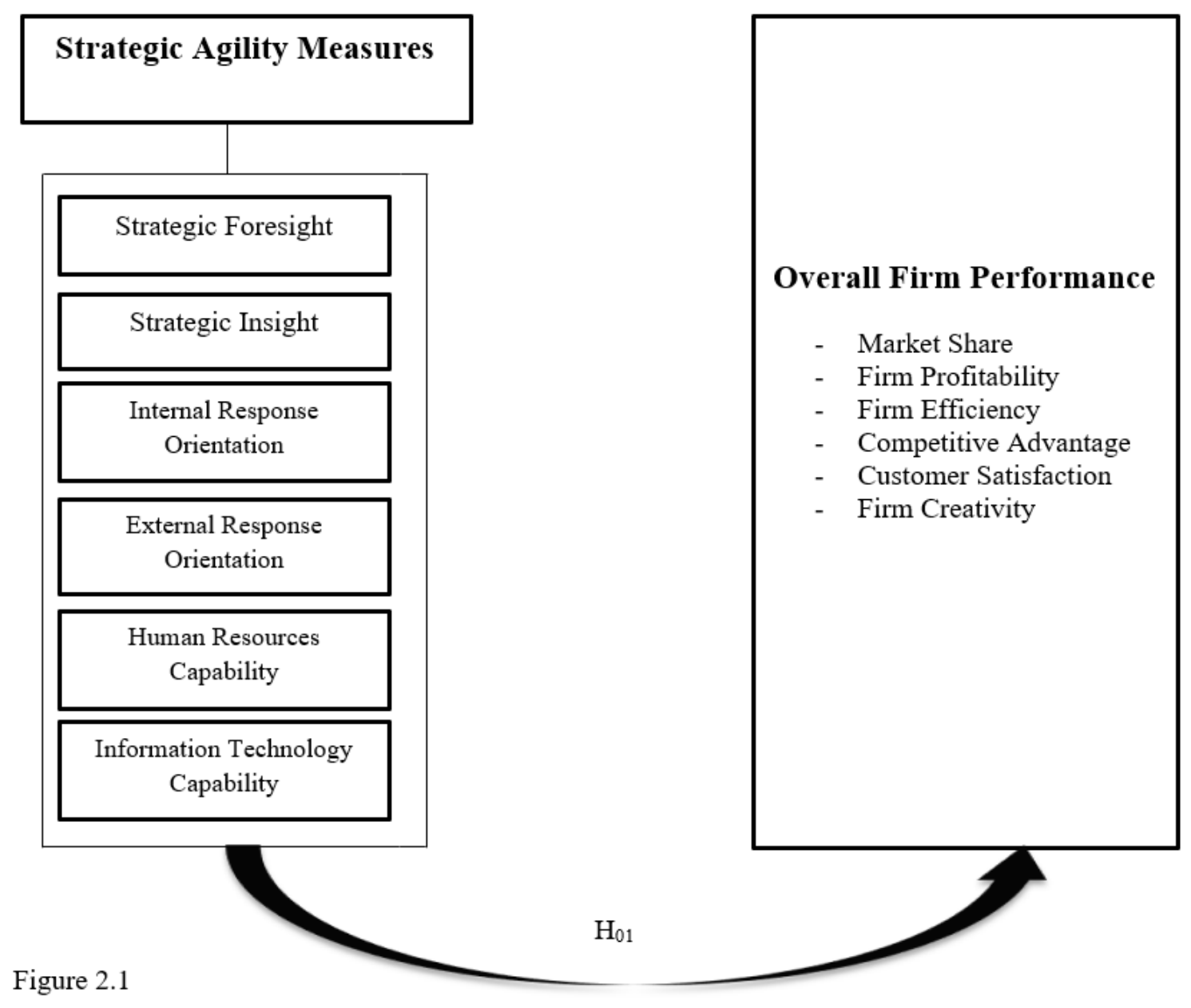

Source: Researcher's Conceptual Model (2021)

Figure 2.1

Source: Researcher's Conceptual Model (2021)

The researcher's conceptual model in Figure 2.1 depicted how strategic agility measures (strategic foresight, strategic insight, internal response orientation, external response orientation, human resources capability, information technology capability) affect overall firm performance which aligned with the hypothesis of the study.

\section{Research Methods}

This paper employed cross-sectional survey research design to gather survey data on the study's dependent and independent variables across selected oil and gas marketing companies in Lagos State, Nigeria in order to examine the effect of strategic agility measures on overall firm performance of these companies. The scope of the study was on the major oil and gas marketing companies in Lagos State, Nigeria such as NNPC Retail Ltd (NRL) and the other major petroleum products marketers like Conoil Plc, $11 \mathrm{Plc}$, Forte Oil Plc, MRS Oil Nigeria Plc, OVH 
Energy Marketing Ltd and Total Nigeria Plc. The unit of analysis of the study was the filling station managers with total enumeration of 515 respondents. This study focused on Lagos State because it serves as hosts to the second highest number of oil and gas retail outlets in the country, the State is the nation's commercial hub, and the State also consumes a significant proportion of the petroleum products locally refined and imported into the country: $16.31 \%$ and $25.89 \%$ of total truck-out of premium motor spirit and automotive gas oil respectively were consumed in the State over the first quarter of 2019 (National Bureau of Statistics, 2020). For this research paper, a six-point modified Likert-type scale was used to elicit responses from every question in the questionnaire and this covered: Very High $(\mathrm{VH})-6$; High $(\mathrm{H})-5$; Moderately High $(\mathrm{MH})$ - 4; Moderately Low (ML) - 3; Low (L) - 2; Very Low (VL) - 1. The questionnaire used for this study have passed through face validity, content validity, construct validity and reliability (internal consistency) tests (See Table 1). In the process, those items in the questionnaire that failed reliability and validity tests were removed from the questionnaire and could not be used as part of items to measure the study variables. Hence, the questionnaire had been statistically certified to correctly and consistently measure the study variables. In this study, 480 questionnaires were retrieved and used for analysis out of 515 administered to the respondents, a response rate of $93.20 \%$. The research paper employed multiple regression method of analysis.

\subsection{The Validity and Reliability Result}

Table 1: KMO, Bartlett's Test of Sphericity and Reliability Results

\begin{tabular}{|l|l|c|c|c|c|c|}
\hline S/N & Variables & $\begin{array}{c}\text { No. of } \\
\text { Items }\end{array}$ & AVE & KMO & $\begin{array}{c}\text { Bartlett } \\
\text { Test }\end{array}$ & $\begin{array}{c}\text { Reliability } \\
\text { (Cronbach Alpha) }\end{array}$ \\
\hline 1 & Strategic Foresight & 7 & 0.684 & 0.592 & 0.000 & 0.729 \\
\hline 2 & Strategic Insight & 9 & 0.753 & 0.627 & 0.000 & 0.801 \\
\hline 3 & $\begin{array}{l}\text { Internal Response } \\
\text { Orientation }\end{array}$ & 7 & 0.578 & 0.449 & 0.024 & 0.713 \\
\hline 4 & $\begin{array}{l}\text { External Response } \\
\text { Orientation }\end{array}$ & 9 & 0.641 & 0.567 & 0.000 & 0.737 \\
\hline 5 & $\begin{array}{l}\text { Human } \\
\text { Capability Resource }\end{array}$ & 10 & 0.716 & 0.610 & 0.000 & 0.723 \\
\hline 6 & $\begin{array}{l}\text { Information Technology } \\
\text { Capability }\end{array}$ & 5 & 0.786 & 0.716 & 0.000 & 0.805 \\
\hline 7 & Firm Performance & 6 & 0.854 & 0.721 & & 0.734 \\
\hline
\end{tabular}

Source: Author's Computation (2021)

The study questionnaire was subjected for validity and reliability tests. The results in Table 1 indicated that the KMO was greater than 0.5 . This means that the questions actually measured the variables in the study. The result of the Bartlett test of Sphericity at 0.000 which was less than 5\%, indicated that there was a high significant relationship among variables under study and that there was no redundancy between the variables that could be summarized with some factors. These also indicated that statements that comprised the research instruments of each variable actually measured what were intended to be measured. The construct validity of the research instrument was further established through confirmatory factor analysis. Average Variance Extracted (AVE) greater than 0.5 was used as an additional evidence of construct validity of all variables in the research instrument. Cronbach's alpha coefficient for each study variable was greater than 0.70 which indicated that the items used to measure the study variables were reliable. To test whether multicollinearity would pose a serious challenge to the study, tests based on Variance Inflation Factor (VIF) and their reciprocal tolerances were conducted (See Table 2). Likewise, regression methods of analyses was employed to test the hypothesis of the study.

\subsection{Model Specification}

The model was denoted based on the hypothesis of the study and stated as:

$\mathrm{Y}=$ Dependent Variable $=$ Overall Firm Performance (OFP)

$\mathrm{X}=$ Independent Variable $=$ Strategic Agility Measures $(\mathrm{SAM})$

Where;

$\mathrm{X}=$ Strategic Agility Measures $(\mathrm{SAM})=\left(\mathrm{x}_{1}, \mathrm{x}_{2}, \mathrm{x}_{3}, \mathrm{x}_{4}, \mathrm{X}_{5}, \mathrm{X}_{6}\right)$

$\mathrm{x}_{1}=$ Strategic Foresight $(\mathrm{SF})$

$\mathrm{x}_{2}=$ Strategic Insight $(\mathrm{SI})$

$\mathrm{x}_{3}=$ Internal Response Orientation (IRO)

$\mathrm{x}_{4}=$ External Response Orientation (ERO)

$\mathrm{x}_{5}=$ Human Resource Capability (HRC)

$\mathrm{x}_{6}=$ Information Technology Capability (ITC)

The model formulated for the study was functionally written as follows based on the objective and hypothesis of the study: 
$\mathrm{Y}=\mathrm{f}\left(\mathrm{x}_{1}, \mathrm{x}_{2}, \mathrm{x}_{3}, \mathrm{x}_{4}, \mathrm{x}_{5}, \mathrm{x}_{6}\right)$

$\mathrm{Y}=\beta_{0}+\beta_{1} \mathrm{x}_{1}+\beta_{2} \mathrm{x}_{2}+\beta_{3} \mathrm{x}_{3}+\beta_{4} \mathrm{x}_{4}+\beta_{5} \mathrm{x}_{5}+\beta_{6} \mathrm{x}_{6}+\varepsilon_{\mathrm{i}}$

$\mathrm{OFP}=\beta_{0}+\beta_{1} \mathrm{SF}_{\mathrm{i}}+\beta_{2} \mathrm{SI}_{\mathrm{i}}+\beta_{3} \mathrm{IRO}_{\mathrm{i}}+\beta_{4} \mathrm{ERO}_{\mathrm{i}}+\beta_{5} \mathrm{HRC}_{\mathrm{i}}+\beta_{6} \mathrm{ITC}_{\mathrm{i}}+\varepsilon_{\mathrm{i}}$

$-\mathrm{H}_{01}$ : Strategic agility measures have no significant effect on overall firm performance of oil and gas marketing companies in Lagos State, Nigeria A priori Expectation: If $\beta_{1}-\beta_{6} \neq 0 \& p \leq 0.05$, Reject null hypothesis

Where $\beta_{0}=$ the constant term; $\beta_{1}-\beta_{6}=$ the regression coefficient for SAM; while lastly, $\varepsilon_{i}=$ Error Term.

\section{Result and Discussions}

This sub-section focused on multicollinearity test and hierarchical regression method of analysis.

Multicollinearity Test

Table 2: Multicollinearity Test Results

\begin{tabular}{|l|c|c|c|}
\hline Variables & Tolerance & VIF & Remark \\
\hline $\mathrm{x}_{1}=$ Strategic Foresight (SF) & 0.521 & 1.918 & No multicollinearity \\
\hline $\mathrm{x}_{2}=$ Strategic Insight (SI) & 0.567 & 1.762 & No multicollinearity \\
\hline $\mathrm{x}_{3}=$ Internal Response Orientation (IRO) & 0.619 & 1.615 & No multicollinearity \\
\hline $\mathrm{x}_{4}=$ External Response Orientation (ERO) & 0.560 & 1.785 & No multicollinearity \\
\hline $\mathrm{x}_{5}=$ Human Resource Capability (HRC) & 0.567 & 1.765 & No multicollinearity \\
\hline $\mathrm{x}_{6}=$ Information Technology Capability (ITC) & 0.664 & 1.506 & No multicollinearity \\
\hline
\end{tabular}

Dependent Variable: Overall Firm Performance

Source: Field Survey Data (2021)

Table 2 shows that the variables have a VIF that is less than 10 and tolerance value more than 0.1 ruling out the possibility of multicollinearity. All the predictor variables had a VIF of less than 10 . The explanatory variables were not highly correlated and could not pose a serious problem. The data was thus suitable for hypothesis testing using regression method of analyses.

\section{Table 3: Linearity Result for Study Variables}

The study tested for the linear relationship between the independent variables and the dependent variable using the Pearson's correlation coefficient and the results are presented in Table 3.

Linearity Test Results

\begin{tabular}{|c|c|c|c|}
\hline \multicolumn{2}{|l|}{$\begin{array}{l}\text { Dependent variable: } \\
\text { Firm Performance }\end{array}$} & Test Results & Conclusion \\
\hline \multirow[t]{3}{*}{ Strategic Foresight } & Pearson Correlation & $.616^{* *}$ & \multirow[t]{3}{*}{ Linear Relationship } \\
\hline & Sig. (2-tailed) & .000 & \\
\hline & $\mathrm{N}$ & 480 & \\
\hline \multirow[t]{3}{*}{ Strategic Insight } & Pearson Correlation & $.556^{* *}$ & \multirow[t]{3}{*}{ Linear Relationship } \\
\hline & Sig. (2-tailed) & .000 & \\
\hline & $\mathrm{N}$ & 480 & \\
\hline \multirow{3}{*}{$\begin{array}{l}\text { Internal Response } \\
\text { Orientation }\end{array}$} & Pearson Correlation & $.592^{* *}$ & \multirow[t]{3}{*}{ Linear Relationship } \\
\hline & Sig. (2-tailed) & .000 & \\
\hline & $\mathrm{N}$ & 480 & \\
\hline \multirow{3}{*}{$\begin{array}{l}\text { External Response } \\
\text { Orientation }\end{array}$} & Pearson Correlation & $.600^{* *}$ & \multirow[t]{3}{*}{ Linear Relationship } \\
\hline & Sig. (2-tailed) & .000 & \\
\hline & $\mathrm{N}$ & 480 & \\
\hline \multirow{3}{*}{$\begin{array}{ll}\text { Human } & \text { Resource } \\
\text { Capability } & \end{array}$} & Pearson Correlation & $.603^{* *}$ & \multirow[t]{3}{*}{ Linear Relationship } \\
\hline & Sig. (2-tailed) & .000 & \\
\hline & $\mathrm{N}$ & 480 & \\
\hline \multirow{3}{*}{$\begin{array}{l}\text { Information } \\
\text { Technology } \\
\text { Capability }\end{array}$} & Pearson Correlation & $.598^{* *}$ & \multirow[t]{3}{*}{ Linear Relationship } \\
\hline & Sig. (2-tailed) & .000 & \\
\hline & $\mathrm{N}$ & 480 & \\
\hline
\end{tabular}

Source: Field Survey Data (2021)

The findings presented in Table 3 indicated that there is a significant positive linear relationship between strategic foresight, strategic insight, internal response orientation, external response orientation, human resource capability, information technology capability and firm performance at $\mathrm{P}<0.05$ significance level. However, it is important to mention that correlation does not necessarily mean that there is a causal relationship (Yount, 2000; Wooldridge, 2000). To this end, it was important to conduct regression analysis in order to estimate the extent of causal relationship among the variables. Since the population was normally distributed, therefore the linear regression was suitable and can be estimated in this study. Accordingly, the proposed models can accurately be estimated.

Study Hypothesis: $\mathbf{H}_{01}$ : Strategic agility measures have no significant effect on overall firm performance of oil 
and gas marketing companies in Lagos State, Nigeria

Table 4: Model Summary of Effects of Strategic Agility Measures on Overall Firm Performance of Selected Oil and Gas Marketing Companies in Lagos State, Nigeria

\begin{tabular}{|c|c|c|c|c|c|c|}
\hline \multirow{2}{*}{\multicolumn{2}{|c|}{ Model }} & \multicolumn{2}{|c|}{$\begin{array}{l}\text { Unstandardised } \\
\text { Coefficients }\end{array}$} & $\begin{array}{l}\text { Standardised } \\
\text { Coefficients }\end{array}$ & \multirow[t]{2}{*}{$\mathrm{T}$} & \multirow[t]{2}{*}{ Sig. } \\
\hline & & $\mathrm{B}$ & $\begin{array}{l}\text { Std. } \\
\text { Error }\end{array}$ & Beta & & \\
\hline \multirow[t]{7}{*}{1} & (Constant) & 11.114 & 2.443 & & 4.550 & 0.000 \\
\hline & Strategic Foresight & 0.381 & 0.070 & 0.250 & 5.445 & 0.021 \\
\hline & Strategic Insight & 0.016 & 0.052 & 0.013 & 2.304 & 0.001 \\
\hline & Internal Response Orientation & 0.351 & 0.065 & 0.226 & 5.362 & 0.050 \\
\hline & External Response Orientation & 0.123 & 0.061 & 0.089 & 1.810 & 0.095 \\
\hline & Human Resource Capability & 0.176 & 0.051 & 0.152 & 3.461 & 0.001 \\
\hline & $\begin{array}{ll}\text { Information } & \text { Technology } \\
\text { Capability } & \end{array}$ & 0.387 & 0.092 & 0.171 & 4.205 & 0.031 \\
\hline & $\begin{array}{l}\text { at Value }=96.622(0.000) \\
.658 \\
\mathrm{R}^{2}=0.792 \\
\text { in-Watson }=1.923\end{array}$ & & & & & \\
\hline
\end{tabular}

Dependent Variable: Overall Firm Performance

Source: Researcher's Results Computation (2021)

Table 4 presented the results of the regression coefficients which revealed that a positive effect was reported for all the components of strategic agility. Further, the results revealed that at $95 \%$ confidence level, strategic foresight $(\beta=0.250, p<0.05)$, strategic insight $(\beta=0.013, p<0.05)$, internal response orientation $(\beta=0.226$, $\mathrm{p}<0.05)$, human resource capability $(\beta=0.152 \mathrm{p}<0.05)$ and information technology capability $(\beta=0.171, \mathrm{p}<0.05)$ were statistically significant as the p-values were less than 0.05 and the t-values greater than 1.96 while external response orientation $(\beta=0.089, p>0.05, t$-value $=1.810)$ had insignificant effect on overall firm performance of selected oil and gas marketing companies in Lagos State, Nigeria. The results implied that all the strategic agility measures except external response orientation had significant positive effect on overall firm performance of selected oil and gas marketing companies in Lagos State particularly when strategic foresight, internal response orientation, human resource capability, and information technology capability initiatives were implemented. The result indicated that strategic foresight has the highest effect compared with strategic insight with the least effect on overall firm performance.

The results obtained was also reliable as given by the Adjusted R value of 0.792 which explained that the results were $79.2 \%$ reliable and therefore the regression model developed can be relied upon to explain $79.2 \%$ trends in the overall firm performance of the selected oil and gas marketing companies. The significance of the model was tested at 5\% level of significance with F-statistic of 96.622 and p-value of 0.000 which indicated that the regression model developed was statistically significant and can be relied upon to explain the effect of strategic agility measures on overall firm performance of selected oil and gas marketing companies. The study model was free from autocorrelation problem, which indicated that the study model was well specified and represented the true picture of the overall firm performance model of the oil and gas marketing companies.

According to the regression equation above, taking all factors constant at zero, overall firm performance of selected oil and gas marketing companies in Lagos State was 11.114. The result indicated that taking all other independent variables at zero, a unit change in each strategic agility measure (strategic foresight, strategic insight, internal response orientation, external response orientation, human resource capability, and information technology capability) will lead to a corresponding increase in overall firm performance $(0.250,0.013,0.226$, $0.089,0.152, \& 0.171)$ of selected oil and gas marketing companies in Lagos State, Nigeria.

Overall from the results, strategic foresight had the highest effect on the overall firm performance of selected oil and gas marketing companies in Lagos State, Nigeria with a coefficient of 0.250 and $t$ value of 5.455, followed by internal response orientation $(\beta=0.226, \mathrm{t}(480)=5.362, \mathrm{p}<0.05)$, information technology capability $(\beta=0.171$, $\mathrm{t}(480)=4.205, \mathrm{p}<0.05)$, and human resource capability $(\beta=0.152, \mathrm{t}(480)=3.461, \mathrm{p}<0.05)$ while strategic insight contributed the least towards the overall firm performance of selected oil and gas marketing companies in Lagos State $(\beta=0.013, \mathrm{t}(480)=2.304, \mathrm{p}<0.05)$. Based on the findings, this study concluded that strategic agility measures significantly affect overall firm performance of selected oil and gas marketing companies in Lagos State, Nigeria.

Therefore, the null hypothesis one $\left(H_{01}\right)$ which states that strategic agility measures have no significant effects on overall firm performance of selected oil and gas marketing companies in Lagos State, Nigeria was rejected. 


\section{Discussion of Finding}

Aligning past related studies with the study finding, most studies revealed that strategic agility (SA) significantly improved firm competitive advantage and overall firm performance across industries (See Alhadid, 2016; AlRomeedy, 2019; Bratianu, 2015; Chirchir, 2015; Hadad, 2017; Okotoh, 2015; Rohrbeck \& Kum, 2018; Salih \& Alnaji, 2014; Sudon, Abareshi, \& Pittayachawan, 2015; Tikkanen, 2014, Tse, Zhang, Akhtar, \& MacBryde, 2016; Uğurlu et al., 2018). Similarly, Clauss et al. (2019), Khan and Wisner (2019), Muthoni (2015) and Ravichandran (2018) established that SA has positive and significant effect on firm competitive capability and operational performance. Furthermore, Lungu (2018) examined the place of SA in the telecom industry in Romania and found that SA represented a path towards sustainability and continuous innovation whose outcome was orientated towards value and delivering best performance; Dehmolaee and Rashnavadi (2019) investigated the effect of SA on the telecommunication business in Iran and found that SA influenced technological capabilities and organizational learning, which in turn influenced competitive advantage and performance of the businesses; Kale, Aknar, and Basar (2019) examined the mediating role of SA in the effect of absorptive capacity on the firm performance of accommodation establishments in Turkey and found that there was a positive correlation between performance and SA; Lungu (2020) in a study of the IT sector in Romania, found that organisations which used SA have an improved performance level than their competitors. Nurjaman et al. (2021) investigated the relationship between SA and competitive strategy as a moderator for the improvement of the firm performance in a logistic service provider company. The study revealed a direct relationship between SA and competitive strategy to the firm performance. The positive effects of SA on organizational performance indicated by these prior studies implies that the attributes of ability (response orientations), openness to surroundings (strategic insight) and ability to detect opportunities (strategic foresight) and take advantages of these opportunities faster than competitors, are necessary to overwhelm and beat market rivals in a rapidly changing business environment. Conversely, Djaja and Arief (2015) found that SA has negative impact on firm profitability; Ojha (2008) revealed that increases in SA did not have any positive effect on firm financial performance but enhanced the competitive capabilities of organisations' operations; and Shin et al. (2015) confirmed that the SA of Korean SMEs did not influence firm financial performance either directly or indirectly through operational responsiveness but had positive influence over operational performance and customer retention. Likewise, Nurjaman et al. (2021) found that SA showed a negative effect on firm performance when competitive strategy was made a moderator.

Moreover, dynamic capabilities theory, the anchored theory, theoretically supported the study finding that the agility, responsiveness and innovativeness of organisations become more timely, rapid and flexible in dynamic markets, thus improving overall firm performance. The theory further stated that firms with greater dynamic capabilities will outperform firms with smaller dynamic capabilities. The theory creates and sustains an operational performance over other firms by responding to and creating environmental changes. Capabilities are a collection of high level, learned, patterned, repetitive behaviors that an organisation can perform better relative to its competition (Winter, 2003). Dynamic capabilities help firm's sense opportunities and then seize them by successfully reallocating resources, often by adjusting existing competencies or developing new ones in order to achieve overall firm performance (Harris, Kaefer, \& Salchenberger, 2013). Dynamic capabilities theory also support SA to enhance overall firm performance: Di Minin, Frattini, Bianchi, Bortoluzzi, and Piccaluga (2014) confirmed SA as a critical dynamic capability necessary to achieve long-term competitive advantage in highly dynamic and turbulent industries; Tikkanen (2014) found that dynamic capabilities do influence parts of SA especially in areas of reaction to market changes and delivering customized solutions, goods and services to customers. Since both the empirical findings and anchored theory supported the study finding that SA measures have significant effect on overall firm performance of selected oil and gas marketing companies in Lagos State, Nigeria, the null hypothesis was therefore rejected.

\section{Implication of Findings}

The findings of the study have the following implications:

i. Specifically, external response orientation did not have a significant positive effect on overall firm performance ( $\mathrm{t}$-value $=1.810<1.96, \mathrm{p}<0.05)$ because of the idiosyncratic features of the industry. External response orientation is the ability of an organization to re-act or pro-act to the business environment (Mavengere, 2013). In the oil and gas industry, there are some critical externalities over which the individual firms, and even nations, do not have control. Hence it is difficult to design a proactive measure that can drive the market. It is when SA initiatives are implemented down the whole spectrum of the process that the organization can institute means of creating and maintaining relationships with a variety of different people and organisations in order to gather as much information and intelligence as possible. This will make the organization to become more pro-active in the process and be ahead of the market.

ii. From the model and the statistical analysis results, it was observed that a unit change in strategic foresight produced the greatest change in overall firm performance. This result attested to the criticality of strategic foresight in the strategic agility implementation programme: it is a must-do antecedent in the process. In a fast-changing 
business environment that is also fraught with lots of externalities, the capability to develop strategic foresight is of paramount importance. It is an antecedent to the capability of an organisation to innovate continuously (Constanzo, 2004). The oil and gas industry operates in such an environment. The significance of strategic foresight and its role in the programme of implementation of strategic agility is made manifest because strategic foresight will enable firms to spot trends ahead of competitors, gain deeper insight into how such emerging trends will affect their organisations and identify the most effective response and ultimately gain a competitive advantage (Rohrbeck \& Kum, 2018). Strategic foresight enhances the ability of firms to identify the factors that drive environmental change, foresee future market changes, and define a course of action that leads towards a superior firm performance (Vecchiato, 2012). It aims to support strategic thinking and decision-making by developing a range of possible ways of how the future could unfold, a major step in sensing the emerging signals from the environment (Cook et al., 2014). Furthermore, exploring the future allows for the possibility of foreseeing breakthroughs, technology leaps, trends and discontinuities and new perspectives that present themselves, all of which are important for strategic planning and support of decision-making (Nehme et al., 2012). Therefore, the significance and value addition of strategic foresight is not in predicting the future but in preparing the organisation to deal with the future by means of a learning process that enhances the ability of the organisation to match itself with its changing environment (Tsoukas \& Shepherd, 2004). Empirically, this is supported by Orojloo et al. (2016) that investigated the effect of SA capabilities and factors on organizational performance and found that among the factors affecting SA, strategic foresight had the highest effect on organizational performance and market share. iii. On the other hand, the result that a unit change in strategic insight produced the least change in overall firm performance could be explained by the sheer speed of changes in the industry especially as regards price volatility and technology which does not give too much room for individual observations and reflection, activities that are key pillars of the qualitative process of strategic insight. Strategic insight is the tendency of an organisation to focus on the present by drawing knowledge from complex strategic situations as they emerge and analysing them for the organisation to benefit from the situations as they unfold (Doz \& Kosonen, 2008). It encompasses both the outside view (or external sensing) and inside view (or internal awareness) (Mavengere, 2013). An organization engages in internal awareness through probing and experimenting, highlighting the organisation's strengths and weaknesses in the light of the environment thereby leading to a challenge of the firm's dominant logic, the core business assumptions of the firm. External sensing on the other hand, enables the executives to see their organisation from different perspectives when they distance themselves from their routine and they start modelling the organisation and its relationship to its environment (Doz \& Kosonen, 2010). These steps are very engaging and they demand that such insight generation practices need to become a habit in order to develop a long-lasting capability that will enhance the positive effect of SA on the overall firm performance of the organization. Therefore, the more time, efforts, attention and resources that are devoted to these activities, the greater both the desired and achieved impact of strategic insight on the overall firm performance of the organisations.

\section{Conclusion and Recommendations}

The study concluded that strategic agility measures affected overall firm performance of oil and gas marketing companies in Lagos State, Nigeria. Therefore, this study recommended that the oil and gas marketing companies should:

1. Embrace the dictates of dynamic capabilities theory in order to enhance strategic agility pattern which will improve their targeted overall performance over their competitors.

2. Be fast in adopting strategic agility measures so as to continuously develop and enhance capabilities for proper and timely sensing of changes in their business environment which will increase their dynamic sensing and seizing of opportunities, thus increasing their overall performance.

3. Develop strategic foresight capabilities across the workforce that will prepare the organizations to deal with the future by means of a learning process.

4. Initiate processes that will enable the organizations to spot trends ahead of competitors, thereby enhancing their ability to be proactive and match themselves with their changing environment.

5. Evolve and establish insight generation practices to become a habit across the workforce as this will lighten the burden of implementation of strategic agility and boost its positive effect on the overall firm performance of the organization.

6. Emphasise the development of strategic agility as a dynamic organizational capability in order to improve and sustain overall firm performance.

\section{Limitations and Suggestions for Further Study}

The study had some inherent limitations which are highlighted here. First, the scope of the study was limited to the petroleum products marketing sector excluding the upstream sector of the industry completely. For a holistic appreciation of the effect of strategic agility measures on the oil and gas industry, the upstream sector requires same study. Second, the sample of the study was restricted to the 515 retail filling stations owned and operated by 
the major petroleum products marketers, thus limiting generalization of the study findings. The sample could be enhanced by either including the stations owned by the independent petroleum products marketers in Lagos State or expanding the current scope of the study to cover beyond Lagos State.

Further studies should: (i) examine the differential impact of strategic agility measures in the study on the overall firm performance of the separate sectors of the oil and gas industry and on the industry as a whole; (ii) investigate the effect of other measures of strategic agility (responsiveness, speed, flexibility, competence, agile mindset) on overall firm performance of the oil and gas industry and compare the results; (iii) determine if there are variables (internal and/or external) that moderate the relationship between strategic agility measures and overall firm performance of the sector and investigate the extent of such moderation; and (iv) assess the effect of the strategic agility measures in the study on the overall firm performance of the oil and gas industry and compare to the results obtained with regard to other industries like airlines, telecommunication, higher education and manufacturing.

\section{References}

Alhadid, A. Y. (2016). The effect of organization agility on organization performance. International Review of Management and Business Research, 5(1), 273-278. 1460608053.pdf

Al-Romeedy, B. S. (2019). Strategic agility as a competitive advantage in airlines-Case study: Egypt air. Journal of the Faculty of Tourism and Hotels-University of Sadat City, 3(1), 1-15.

Alon, I., Madanoglu, M., \& Shohan, A. (2017). Strategic agility explanations for managing franchising expansion during economic cycles. Journal of Global Competitiveness, 27(2), 113-131. DOI: 10.1108/CR-04-20160022 .

Ambrosini, V., Bowman, C., \& Collier, N. (2009). Dynamic capabilities: An exploration of how firms renew their resource base. British Journal of Management, 20(1), 9-24. doi.org/10.1111/j.1467-8551.2008.00610.x

Amniattalab, A., \& Ansari, R. (2016). The effect of strategic foresight on competitive advantage with the mediating role of organisational ambidexterity. International Journal of Innovation Management, 20(3), 1650040. doi.org/10.1142/S1363919616500407.

Amin-Beidokhti, A. A., \& Zargar, S. M. (2012). Pathology of small and medium enterprises (SMEs) and practical strategies to support them (Semnan Province Case Study). Quarterly Journal of Management and Development Process, 24(4), 125-156. https://www.sid.ir/en/journal/ViewPaper.aspx?id=374833

Anggraini, W., \& Sudhartio, L. (2019). Strategic agility in environmental turbulence. A case of banking sector in Indonesia. Conference: Proceedings of the 1st Sampoerna University-AFBE International Conference, SUAFBE 2018, 6-7 December 2018, Jakarta Indonesia. DOI: 10.4108/eai.6-12-2018.2286279

Appelbaum, S. H., Calla, R., Desautels, D., \& Hasan, L. (2017). The challenges of organizational agility (Part 1). Industrial and Commercial Training, 49(1), 6-14. DOI: 10.1108/ICT-05-2016-0027.

Arbussa, A., Bikfalvi, A., \& Marquès, P. (2017). Strategic agility-driven business model renewal: The case of an SME. Management Decision, 55(2), 271- 293. DOI: 10.1108/MD-05-2016-0355

Arokodare, M. A. (2020). Strategic agility and firm performance of selected oil and gas marketing companies in Lagos State, Nigeria. (PhD Thesis). Babcock University, Nigeria.

Arokodare, M. A., \& Asikhia, O. U. (2020). Strategic agility: Achieving superior organizational performance through strategic foresight. Global Journal of Management and Business Research, 20(3), 7-16. https://journalofbusiness.org/index.php/GJMBR/article/view/3025

Arokodare, M. A., Makinde, G. O., \& Fakunmoju, S. K. (2020). Strategic agility and competitive advantage of oil and gas marketing companies: The moderating effect of information technology capability and strategic foresight. International Journal of Advanced Research, 8(08), 1393-1406. Doi: 10.21474/IJAR01/11627

Bleady, A., Ali, A. H., \& Ibrahim, S. B. (2018). Dynamic capabilities theory: Pinning down a shifting concept. Academy of Accounting and Financial Studies Journal, 22(2), 1-16.

Brătianu, C. (2015). Developing strategic thinking in business education. Management Dynamics in the Knowledge Economy, 3(3), 409-429.

Chirchir, E. (2015). Relationship between organizational agility and operational productivity at Kenya Ports Authority. Unpublished MBA project. University of Nairobi.

Clauss, T., Abebe, M., Tangpong, C., Hock-Dopgen, M. (2019). Strategic agility, business model innovation and firm performance: An empirical investigation. IEEE Transactions on Engineering Management, 1-18. https://doi.org/10.1109/TEM.2019.2910381.

Constanzo, L. A. (2004). Strategic foresight in a high-speed environment. Futures, 36(2), 219-235.

Cook, C. N., Inayatullah, S., Burgman, M. A., Sutherland, W. J., \& Wintle, B. A. (2014). Strategic foresight: How planning for the unpredictable can improve environmental decision-making. Trends in Ecology \& Evolution, 29(9), 531-541.

Dehmolaee, S., \& Rashnavadi, Y. (2019). Strategic agility in telecom industry: The effective factors on competitive advantages. Middle East Journal of Management, 6(1), 1-20. DOI: 10.1504/MEJM.2019.097361 
Di-Minin, A., Frattini, F., Bianchi, M., Bortoluzzi, G., \& Piccaluga, A. (2014). Udinese Calcio soccer club as a talents factory: Strategic agility, diverging objectives, and resource constraints. European Management Journal, 32(2), 319-336. https://doi.org/10.1016/j.emj.2013.04.001

Djaja, I., \& Arief, M. (2015). The impact of dynamic information technology capability and strategic agility on business model innovation and firm performance on ICT firms. Advanced Science Letters, 21(5), 1225-1229. https://doi.org/10.1166/asl.2015.6105

Doz, Y., \& Kosonen, M. (2008). The dynamics of strategic agility: Nokia's rollercoaster experience. California Management Review, 50(3), 95-118. DOI: 10.2307/41166447

Doz, Y. L., \& Kosonen, M. (2010). Embedding strategic agility: A leadership agenda for accelerating business model renewal. Long Range Planning, 43(2-3), 370-382.

Easterby-Smith, M., Lyles, M. A., \& Peteraf, M. A. (2009). Dynamic capabilities: Current debates and future directions. British Journal of Management, 20, S1-S8. DOI: 10.1111/j.1467-8551.2008.00609.x

Engebretsen, R., \& Anderson, C. (2020). The impact of coronavirus (COVID-19) and the global oil price shock on the fiscal position of oil exporting developing countries. OECD Publications.https://read.oecdilibrary.org/view/?ref=136_136801aw9nps8afk\&title=The impact-of-Coronavirus-COVID-19-and-theglobal-oil-price-shock-on-the-fiscal-position-of-oil-exporting-developing-countries (Accessed on $28^{\text {th }}$ December, 2020).

Esbach, J. (2009). Relevance of engineering entrepreneurship: A study at Cape Peninsula University of Technology. Journal of Asia Entrepreneurship and Sustainability, 5(3), 108-121.

Hadad, S. (2017). Knowledge economy: Characteristics and dimensions. Management Dynamics in the Knowledge Economy, 5(2), 203-225. https://doi.org/10.25019/MDKE/5.2.03

Harris, D. A., Kaefer, F., \& Salchenberger, L. M. (2013). The development of dynamic capabilities through organisational and managerial processes. International Journal of Business Environment, 5(4), 398-412.

International Energy Agency (IEA) (2020). The global oil industry is experiencing a shock like no other in its history, IEA, Paris https://www.iea.org/articles/the-global-oil-industry-is-experiencing-shock-like-no-otherin-its-history

Kale, E., Aknar, A., \& Başar, Ö. (2019). Absorptive capacity and firm performance: The mediating role of strategic agility. International Journal of Hospitality Management, 78, 276-283. DOI: 10.1016/j.ijhm.2018.09.010

Lewis, M. W., Andriopoulos, C., \& Smith, W. K. (2014). Paradoxical leadership to enable strategic agility. California Management Review, 56(3), 58-77. doi: 10.1525/cmr.2014.56.3.58

Lungu, M. F. (2018). Achieving strategic agility through business model innovation: The case of telecom industry. Proceedings of the 12th International Conference on Business $\quad$ Excellence $2018 . \quad$ DOI: 10.2478/picbe-2018-0050, 557-567.

Lungu, M. F. (2020). The influence of strategic agility on firm performance. Proceedings of the 14th International Conference on Business Excellence, 102-110. DOI:10.2478/picbe 2020-0011.

Mavengere, N. B. (2013). Information technology role in supply chain's strategic agility. International Journal of Agile Systems and Management, 6(1), 7-24. DOI: 10.1504/IJASM.2013.052209

Mojarad, A. A. S., Atashbari, V., \& Tantau, A. (2018). Challenges for sustainable development strategies in oil and gas industries. Proceedings of the 12th International Conference on Business Excellence, 626-638. DOI:10.2478/picbe-2018-0056.

Muthoni, A. M. (2015). Influence of strategic agility on competitive capability of private universities in Kenya. (Unpublished MBA Project). University of Nairobi.

National Bureau of Statistics (2020). Statistical Bulletin. https://www.nigerianstat.gov.ng.

Nazir, S., \& Pinsonneault, A. (2012). IT and firm agility: An electronic integration perspective. Journal of the Association for Information Systems, 13(3), 150-171. DOI: $10.17705 / 1$ jais.00288

Nehme, C. C., Santos, M. M., Filho, F. L., \& Coelho, M. G. (2012). Challenges in communicating the outcomes of a foresight study to advise decision-makers on policy and strategy. Science and Public Policy, 39(2), 245257.

Nejatian, M., Zarei, M. H., Nejati, M., \& Zanjirchi, S. M. (2018). A hybrid approach to achieve organizational agility: An empirical study of a food company. Benchmarking: An International Journal, 25(1), 201-234. 160050967.pdf

Ojha, D. (2008). Impact of strategic agility on competitive capabilities and financial performance (Doctoral Dissertation). Clemson University.

Ofoegbu, O. E., \& Akanbi, P. A. (2012). The influence of strategic agility on the perceived performance of manufacturing firms in Nigeria. The International Business \& Economics Research Journal, 11(2), 153-169. doi.org/10.19030/iber.v11i2.6769.

Okotoh, A. K. (2015). Influence of organisational agility on operational performance of Trademark East Africa. (A Master Thesis). University of Nairobi.

Orojloo, M., Feizi, K., \& Najafabadi, M. H. (2016). Strategic agility capabilities, factors and their effect on 
organizational performance: A case study of Iranian banks. International Journal of Humanities, 24(4), 84105. http://eijh.modares.ac.ir/article-27-3821-en.html

Oyedijo, A. (2012). Strategic agility and competitive performance in the Nigerian telecommunication industry: An empirical investigation. American International Journal of Contemporary Research, 2(3), 227-237.

Oyerinde, A. J., Olatunji, O. C., \& Adewale, O. A. (2018). Corporate social responsibility and performance of oil and gas industry in Nigeria. EKSU Journal of the Management Scientists, 2(1), 97-106.

PricewaterhouseCoopers (PWC) Report (2019). https://www.pwc.com/gx/en/ceo-survey/2019/Themeassets/reports/pwc-2019-ceo-survey-oil-and-gas-report.pdf

Queiroz, M., Tallon, P. P., Sharma, R., \& Coltman, T. (2018). The role of IT application orchestration capability in improving agility and performance. The Journal of Strategic Information Systems, 27(1), 4-21. DOI: 10.1016/j.jsis.2017.10.002

Rohrbeck, R., \& Kum, M. E. (2018). Corporate foresight and its impact on firm performance: A longitudinal analysis. Technological Forecasting and Social Change, 129, 105-116. DOI: 10.1016/j.techfore.2017.12.013

Salih, A. A., \& Alnaji, L. (2014). Impact of strategic thinking and strategic agility on strategic performance: A case study of Jordanian insurance industry companies. International Review of Management and Business Research, 3(4), 1871-1882. https://www.irmbrjournal.com/papers/1418115238.pdf

Shin, H., Lee, J. N., Kim, D., \& Rhim, H. (2015). Strategic agility of Korean small and medium enterprises and its influence on operational and firm performance. International Journal of Production Economics, 168, 181196. DOI: 10.1016/j.ijpe.2015.06.015

Sudon, A., Abareshi, P., \& Pittayachawan, S. (2015). Agility enablers, capabilities and performance: Thai automotive part industry. Journal of Business Research, 65(56), 579-585.

Tabe-Khoshnood, N., \& Nematizadeh, S. (2017). Strategic agility and its impact on the competitive capabilities in Iranian private banks. International Journal of Business and Management, 12(2), 220- 229. DOI:10.5539/ijbm.v12n2p220.

Tallon, P. P., \& Pinsonneault, A. (2011). Competing perspectives on the link between strategic information technology alignment and organizational agility: Insights from a mediation model. Management Information System Quarterly, 35(2), 463-486. https://aisel.aisnet.org/misq/vol35/iss2/12/

Teece, D. J., Pisano, G., \& Shuen, A. (1997). Dynamic capabilities and strategic management. Strategic Management Journal, 18(7), 509-533. doi.org/10.1002/(SICI)1097-0266(199708)18:7<509: AIDSMJ882>3.0.CO;2-Z

Teece, D. J. (2007). Explicating dynamic capabilities: The nature and microfoundations of (sustainable) enterprise performance. Strategic Management Journal, 28(13), 1319-1350. https://doi.org/10.1002/smj.640

Tikkanen, J. (2014). Dynamic capability influence on strategic agility: A case study in energy conservation industry. Unpublished Master`s Project. University of Oulu.

Tse, Y. K., Zhang, M., Akhtar, P., \& MacBryde, J. (2016). Embracing supply chain agility: An investigation in the electronics industry. Supply Chain Management: An International Journal, 21(1), 140-156. https://doi.org/10.1108/SCM-06-2015-0237

Tsoukas, H., \& Shepherd, J. (2004). Coping with the future: Developing organizational foresightfulness. Future, 36(2), 137-144. DOI: 10.1016/S0016-3287(03)00146-0

Uğurlu, O. Y., Çolakoğlu, E., \& Öztosun, E. (2018). Strategic agility and firm performance relationship: A research in manufacturing firms. International Applied Social Sciences Congress, 278-285.

Winter, S. G. (2003). Understanding dynamic capabilities. Strategic Management Journal, 24(10), 991-995. DOI: $10.1002 /$ smj.318

Wooldridge, M. (2000). The computational complexity of agent design problems. In Proceedings Fourth International Conference on Multi Agent Systems, 341-348.

Yount, R. W. (2000). Research Design \& Statistical Analysis in Christian Ministry. South Western: NAPCE Publishers.

Zahra, S. A., Sapienza, H. J., \& Davidsson, P. (2006). Entrepreneurship and dynamic capabilities: A review, model and research agenda. Journal of Management Studies, 43(4), 917-955. doi.org/10.1111/j.14676486.2006.00616.x

Zaridis, A. D., \& Mousiolis, D. T. (2014). Entrepreneurship and SME's organisational structure: Elements of a successful business. Procedia-Social and Behavioral Sciences, 148, 463-467. https://doi.org/10.1016/j.sbspro.2014.07.066 